\title{
Происхождение российских автохтонных сортов винограда
}

\author{
Петрова К.О.*, Корженков А.А., Федосов Д.Ю., Тощаков С.В. \\ Наииональный исследовательский центр «Курчатовский институт», ЦГИМУ Курчатовский \\ геномный центр, Москва, Россия \\ *Petrova_KO@nrcki.ru
}

Ключевые слова: виноград, однонуклеотидные полиморфизмы, секвенирование, филогенетика

\begin{abstract}
Мотивация и цель: Современные методы определения видовой и сортовой принадлежности винограда Vitis легли в основу нескольких баз данных, которые имеют практическое применение для виноградарей и селекционеров. Целью данной работы является разработка панели праймеров для автоматизированной верификации сортов винограда, паспортизации автохтонных российских сортов, установления происхождения и выявления филогенетических взаимосвязей на основе информации об однонуклеотидных полиморфизмах (SNP).
\end{abstract}

Meтоды $u$ алгоритмы: Для амплификации регионов с SNP проводили мультиплексную ПЦР. Секвенировали на приборе Illumina NovaSeq 6000. Для выравнивания на геном (GCF_000003745.3) использовали bowtie2, для поиска вариантов - bcftools. Для оценки эволюционного расстояния между образцами использовали расстояния Хэмминга. Попарные расстояния кластеризовали с помощью библиотеки Scipу с использованием метода average (UPGMA).

Pезультаты: В работе использовали 7 донских сортов, которые генотипировали по 524 локусам с SNP, и 783 сорта винограда, доступных в базе данных [1]. Такое количество локусов было получено из ранее опубликованного набора $10000 \mathrm{SNP}$ путем отбора SNP с частотой минорных аллелей больше 0.45 , удаления локусов, координаты SNP в которых не совпадали с координатами в сборке генома и расположенных менее чем в 150 п.н. от повторенных последовательностей. Исследования показали, что часть сортов завезена из Европы - Пухляковский, идентичный сорту Коарнэ альба (Румыния), и Сибирьковый, являющийся результатом скрещивания сорта Пухляковский с донским автохтонным сортом Бурый. Другие сорта - Красностоп Золотовский, Цимлянский черный, Варюшкин, Плечистик и Кумшацкий белый - прямых связей с изученными западноевропейскими, кавказскими и балканскими сортами не имеют.

Заключение: В этой работе были проанализированы SNP винограда с целью создания панели праймеров для верификации сортов винограда. Ограниченный набор SNP оказался надежным инструментом не только для идентификации сортов, но и для определения расстояний между сортами и родственных связей.

Благодарности: Работа выполнена в Центре геномных исследований мирового уровня «Курчатовский геномный центр» в рамках приказа «О продолжении научно-исследовательской работы по теме "Нанобиосенсорные системы и биоэнергетика"» № 1056 от 02.07.2020.

\section{Список литературь}

1. Laucou V. et al. Extended diversity analysis of cultivated grapevine Vitis vinifera with $10 \mathrm{~K}$ genome-wide SNPs. PLoS One. 2018;13:e0192540. DOI 10.1371/journal.pone.0192540. 